me.gov.ua/Documents/Detail?lang=uk-UA\&id=224691034e36-4d41-b1bf-288338b3c7fa\&title=RestrProfesiinikhStan dartiv (data zvernennia: 22.03.2021). [in Ukrainian].

Bekh, I., Zhurba, K. (2017). Kontseptsiia formuvannia u pidlitkiv natsionalno-kulturnoi identychnosti u zahalnoosvitnikh navchalnykh zakladakh [The concept of national and cultural identity formation in adolescents at secondary schools]. Hirska shkola ukrainskykh Karpat. № 16. S. 24-33. URL: https://core.ac.uk/download/ pdf/154283942.pdf (data zvernennia: 07.02.2021). [in Ukrainian].
Erikson, E. (1996). Detstvo i obshchestvo [Childhood and society]; per. s angl. Sankt-Peterburg: Lenato, AST, Fond «Universitetskaya kniga». 592 s. [in Russian].

Kushnir, R. (2015). Treti 100000 krokiv do uspikhu [The third 100,000 steps to success]. Drohobych: Kolo. 152 s. [in Ukrainian].

Velykyi tlumachnyi slovnyk suchasnoi ukrainskoi movy [Great explanatory dictionary of modern Ukrainian language] (2005) / ukl. i hol. red. V. T. Busel. Kyiv; Irpin: Perun. 1728 s. URL: http://irbis-nbuv.gov.ua/ulib/ item/UKR0000989 (data zvernennia: 30.04.2021). [in Ukrainian].

Дата надходження до редакиї: 21.05.2021 p.
УДК 37.018.32:316.362

DOI: $10.37026 / 2520-6427-2021-106-2-88-93$
Катерина КОВАЛЬ,

здобувачка $\mathrm{PhD}$

Рівненського державного

гуманітарного університету,

м. Рівне, Украӥна

ORCID: 0000-0002-8139-1941

e-mail: Kateryna.koval@rshu.edu.ua

\title{
СТАНОВЛЕННЯ ДИТЯЧОГО БУДИНКУ СІМЕЙНОГО ТИПУ ЯК ОСВІТНЬОГО ФЕНОМЕНУ
}

Анотація. У статті схарактеризовано особливості становлення сочіального інституту виховання дітей-сиріт та дітей, позбавлених батьківського піклування, - дитячого будинку сімейного типу. Досліджено історичні передумови сімейного виховання дітей без батьківської опіки. Проаналізовано нормативно-правову базу організаиії дитячого будинку сімейного типу. Окреслено специфіку освітньо-виховної та сочіалізуючої діяльності дитячого будинку сімейного типу, де поєднуються родинне оточення та педагогічні методи соиіалізації.

Висвітлено поетапність діяльності дитячого будинку сімейного типу: підготовчий проиес батьків-вихователів, прийом дітей, період адаптаиії та взаємодії всіх членів родини. Підкреслено, щзо для коригування поведінки важливим є розуміння психологічного розвитку вихованців. Розкрито механізми педагогічного впливу та умови становлення особистості вихованців на прикладі батьків-вихователів за умови налагодження комунікаиії та емоційного контакту між дітьми та батьками, залучення всіх до прийняття рішень та створення позитивного освітньо-виховного й соціалізуючого середовищза.

Ключові слова: дитячий будинок сімейного типу, діти-сироти, діти, позбавлені батьківського піклування, батьки-вихователі, сімейна форма виховання, адаптація, соціалізація.

\author{
Kateryna KOVAL, \\ PhD graduate student \\ Rivne State University for the Humanities, \\ Rivne, Ukraine \\ ORCID: 0000-0002-8139-1941 \\ e-mail: Kateryna.koval@rshu.edu.ua
}

\section{ESTABLISHMENT OF A FAMILY TYPE ORPHANAGE AS AN EDUCATIONAL PHENOMENON}

\author{
Abstract. The article has characterized the \\ peculiarities of the establishment of a family type orphanage \\ as a social institution for upbringing orphans and children
}

whose parents were deprived of parental rights. The article has examined historical preconditions of the priority of family upbringing of children without parental care. 
The article has also analyzed the legal framework that defines child protection in our country as a strategic national priority and establishes the basic principles of state policy in the field of realization of children's rights to life, health care, development and education, social protection, as well as the right for a name, nationality, and living in a family environment.

The article has explored the specifics of educational and socializing activities of a family type orphanage, which combines the family environment and pedagogical methods of socialization. The educational functions of this institution directly affect the involvement of a child in social life. The nature of the relationship between students and educators is based on the attitude of mutual interest. Not a big number of children allow their parents to apply individual and comprehensive approaches and control negative manifestations and influences.

The article has described the phased activity of a family type orphanage: the preparatory process of foster parents, adoption of children, the period of adaptation and interaction of all family members. Social support is a mechanism for providing assistance by specialists of the centers of social services for families, children and youth. This mechanism aims to establish cooperation with various professionals to ensure appropriate conditions for education in a family type orphanage.

The pedagogical influence is directed on comprehensive and harmonious development of children based on revealing their interests and needs. Understanding of the psychological development of students is necessary for behavior correction. The article defines the mechanisms of pedagogical influence and conditions of formation of students' personality on the example of foster parents, provided communication and emotional contact between children and parents are established, everyone is involved in decision-making and a positive educational and socializing environment is created.

Key words: family type orphanage, orphans, children deprived of parental care, foster parents, family form of education, adaptation, socialization.

Постановка проблеми. Соціально-економічний та соціокультурний розвиток держави сьогодні беззаперечно залежить від інтелектуально розвиненого, духовно збагаченого і фізично здорового підростаючого покоління. У зв'язку з цим пріоритетом сучасної освіти, виховання і соціалізації $є$ створення комфортних педагогічно орієнтованих умов гармонійного розвитку дитини та захисту іï прав і свобод. Проте аналіз сучасної теорії виховання і освітньо-виховної практики свідчить про те, що діти-сироти та діти, позбавлені батьківського піклування, такої змоги зазвичай не мають. Зважаючи на це, проблема соціального становлення таких дітей на сьогодні $є$ досить актуальною, оскільки за таких умов порушується одне з основних прав дитини - право на сімейне виховання. Актуальність і недостатня ефективність вирішення означеної проблеми стали поштовхом до створення найбільш подібної до виховання дитини у сім’ї організаційно-педагогічної структури - дитячого будинку сімейного типу (далі - ДБСТ).

Однак розуміння складності розв'язання цієї проблеми як у соціально-економічному аспекті, так і щодо створення комфортного виховного середовища, завдяки налагодженню міжособистісної комунікації у вихованні дитини, адекватного батьківського піклування стосовно розвитку її інтересів, освітніх потреб, бажань, захисту прав і надання свободи особистісної діяльності на шляху самостановлення є причинами появи страху в кандидатів у батьки-вихователі. Пріоритетними напрямами вирішення означеної проблеми є: налагодження державної підтримки діяльності дитячого будинку сімейного типу; педагогічна освіта батьків; створення соціального іміджу відповідних закладів виховання дитини; забезпечення ефективності функціонування дитячого будинку сімейного типу; якісне підвищення процесів виховання та соціалізації дітей-сиріт і дітей, позбавлених батьківського піклування.

Аналіз наукових досліджень і публікацій. Дослідженню специфіки виховання дитини в сім'ї як найбільш комфортному для її життєдіяльності і зростання середовищі присвячено наукові праці Й. Песталоцці, М. Драгоманова, А. Макаренка, В. Сухомлинського. Сутнісні характеристики сімейного виховання дітей, позбавлених батьківського піклування, знайшли своє відображення у працях Г. Бевза, І. Пєша, І. Долі, А. Капської, О. Безпалько, В. Яковенка. Аналіз специфіки створення і розвитку дитячого будинку сімейного типу як освітньо-виховного закладу в історико-педагогічному вимірі, умов виховання і соціалізації дитини, дотримання ії̈ прав та свобод у його стінах здійснили О. Свіжий, В. Москалюк, В. Євко, О. Карпенко, Л. Токарчук, Ю. Червоналюк, Л. Лешанич. Окремим питанням виховання дітей-сиріт різного віку та дітей, позбавлених батьківського піклування, у дитячому будинку сімейного типу присвячено наукові праці Л. Артюшкіна, Л. Єременко, Н. Рєпи, В. Яковенка.

Метою статті $\epsilon$ здійснити аналіз генези досліджуваної проблеми, проаналізувати процес становлення будинку сімейного типу, з'ясувати педагогічні особливості та умови виховання дітей-сиріт та дітей, позбавлених батьківського піклування, а також обгрунтувати ефективне функціонування цього соціального інституту в сучасних соціокультурних умовах як соціально-педагогічного феномену.

Виклад основного матеріалу дослідження. Сiмейна форма виховання дітей-сиріт мала прояви у різні історичні періоди становлення і розвитку суспільства. Так, у період створення первинних родинних відносин подружжя або окремі особи могли брати на виховання дітей та утримувати за це винагороди з боку роду, що був у ті часи, у початковому значенні цього поняття, прототипом сучасного соціального органу опіки (рід, родина, плем'я, громада тощо), а отже, здійснював нагляд за адаптацією дітей у сім'ї. Кількість дітей у таких сім'ях могла бути необмеженою.

Із процесом створення держав та укладання законів формується і політика стосовно дітей-сиріт. Так, у Київській Русі за часів правління Ярослава Мудрого був написаний збірник «Руська правда», у якому схарактеризовані правила опіки на державному рівні. Милосердя до дітей та турбота про них стали поширюватися із зміцненням християнського світогляду. Основою такого ставлення стала одна із головних заповідей християнства - любов до ближнього. 
Крім того, у слов'янських державах таких дітей вважали «божими людьми» (Харчук, 2011, с. 189). У подальші історичні періоди вони виховувалися при церквах та у більш заможних сім'ях, де використовували їхню працю та навчали певному заняттю. Уже з XIX століття створюються перші виховні заклади для дітей-сиріт та дітей, позбавлених батьківського піклування, виникає нова форма опіки - патронацтво.

Різноманітні соціально-економічні, політичні, культурно-просвітницькі події впливали й на процес утримання дітей, позбавлених батьківського піклування. На початку XX ст. у зв'язку із світовими та громадянськими війнами значно збільшилася кількість дітей-сиріт, що стало передумовою створення таких державних установ як будинок малюка, дитячий будинок. Метою таких закладів було забезпечення належних умов утримання та догляду якнайбільшої кількості дітей, позбавлених батьківського піклування (Нариси з історії українського шкільництва, 1996).

Зі становленням Радянського Союзу загальнодержавна політика стосовно дітей-сиріт спрямовувалась на зменшення їхньої кількості та розширення мережі дитячих будинків, що створювалися при підприємствах, колгоспах і навіть як окремі заклади освіти, виховання i «привчання дитини до праці»-дитячі колонії. Яскравим прикладом цього була дитяча трудова колонія на чолі з її керівником - талановитим педагогом і вихователем А. Макаренком (Полтавська трудова колонія ім. М. Горького в документах і матеріалах, 2001).

Лише в кінці XX століття відбулися зміни державної політики щодо покращення умов навчання, виховання та матеріального забезпечення дітей-сиріт та дітей, позбавлених батьківського піклування. В основу такої політики покладено принципи сімейного виховання на прикладі створеної у 1949 році Германом Гмайнером австрійської системи функціонування дитячих містечок для дітей-сиріт SOS-Kinderdorf як незалежної, неурядової, соціально спрямованої благодійної організації. Метою організації був захист прав та інтересів дітей, які залишилися без батьківської опіки, сприяння розвитку та створення умов виховання дітей-сиріт, наближених до сімейних.

Водночас у радянській педагогічній, а пізніше і у виховній практиці була запропонована нова форма виховання дітей, позбавлених батьківського піклування, що отримала назву «дитячий будинок сімейного типу». Початок функціонування означених закладів в Україні був затверджений постановою Ради Міністрів СРСР «Про створення дитячих будинків сімейного типу» та Тимчасовим положенням про дитячі будинки сімейного типу (Про створення в республіці дитячих будинків сімейного типу, 1988). Це свідчило про зміну підходів до утримання дітей-сиріт, зокрема виховання їх у сімейному оточенні та взаємній відповідальності кожного члена родини. Відповідно до цієї постанови до дитячих будинків сімейного типу також було включено дитячі містечка з одноквартирних багатокімнатних будинків для проживання сімей, що виховують не менш як 10 дітей-сиріт і дітей, які залишилися без піклування батьків, а також окремі сім’і, що виховують не менш як 5 дітей-сиріт і дітей, позбавлених батьківського піклування, та проживають в багатокімнатних окремих квартирах у звичайних будинках, спеціалізованих будинках або в групах таких будинків. У цьому документі визначалися педагогічні особливості діяльності дитячих будинків сімейного типу, зокрема використання передових форм суспільного та індивідуального виховання, навчання батьків-вихователів та розроблення рекомендацій із конкретних питань виховання (Про створення в республіці дитячих будинків сімейного типу, 1988).

У зв'язку зі збільшенням кількості дитячих будинків сімейного типу в незалежній Україні виникла необхідність створення нового нормативно-правового забезпечення їх діяльності. Із цією метою 27 квітня 1994 року Кабінет Міністрів України прийняв постанову № 267 «Про затвердження положення про дитячий будинок сімейного типу». В означеному документі першим пунктом визначено мету дитячого будинку сімейного типу як поєднання громадських, колективних і родинних форм виховання (Положення про дитячий будинок сімейного типу, 1994).

Зі створенням нових дитячих будинків сімейного типу та зміною законодавства таке положення вимагало змін та уточнень. Це стало причиною прийняття нового нормативного документа - положення про дитячий будинок сімейного типу (Постанова Кабінету Міністрів України від 26 квітня 2002 р. № 564), у змісті якого актуалізовано увагу на необхідності створення належних умов для гармонійного розвитку дітей-сиріт та дітей, позбавлених батьківського піклування, у сімейному оточенні. Крім того, Сімейним кодексом України регулюється функціонування дитячих будинків сімейного типу як окремої сім'ї, що створюється за бажанням подружжя або окремої особи, яка не перебуває в шлюбі, для забезпечення сімейним вихованням та спільного проживання не менше як п'яти дітей-сиріт і дітей, позбавлених батьківського піклування (Сімейний кодекс України, 2002).

Норми Сімейного кодексу України та положення про дитячий будинок сімейного типу передбачають низку особливостей цього соціального інституту, зокрема: волевиявлення осіб для створення дитячого будинку сімейного типу; навчання майбутніх батьків-вихователів; забезпечення необхідних умов для функціонування сім'і; укладання договору між органами опіки та батьками-вихователями; контроль за діяльністю закладу та умовами утримання дітей-сиріт та дітей, позбавлених батьківського піклування. Відповідно до схарактеризованих нами нормативно-правових документів контроль з боку держави виконують місцеві органи опіки і піклування та служби у справах дітей. Такий підхід можна розглядати як делегування державою батькам-вихователям права на виховання дітей, позбавлених батьківського піклування. Саме батьки несуть відповідальність за життя, здоров'я, фізичний та психічний розвиток дітей, є захисниками їхніх прав та інтересів.

Захист прав дітей-сиріт та дітей, позбавлених батьківського піклування, регулюється Законом України «Про охорону дитинства» (2001), Конституцією України, Сімейним кодексом України, Концепцією виховання дітей та молоді у національній системі освіти (1996), Концепцією національно-патріотичного виховання дітей 
та молоді (2015), Конвенцією прав дитини ООН тощо. Основною метою законодавчої бази щодо виховання гармонійної особистості є розвиток соціально адаптованої та активної особистості, формування національної свідомості та відчуття громадянської приналежності незалежно від етнічного походження. Основними завданнями виховання є розвиток особистості дитини, i. здібностей, обдарувань, формування поваги до прав та свобод людини і громадянина, свідомого ставлення до обов'язків та відповідальності перед законом. Усе це свідчить, що на сучасному етапі в Україні змінено акценти на пріоритетність сімейного виховання дітей-сиріт та дітей, позбавлених батьківського піклування, сформовано нормативно-правове підгрунтя розвитку дитячого будинку сімейного типу, а також налагоджено систему забезпечення необхідних для цього умов.

Сьогодні дитячі будинки сімейного типу матеріально та фінансово підтримуються державою. Відповідно державними органами надається необхідна житлова площа $з$ меблями та побутовою технікою, земельна ділянка і транспортний засіб. Соціальна підтримка держави реалізується у формі супроводження фахівцями служб для дітей, сім’і та молоді. Враховуючи основну виховну мету дитячих будинків сімейного типу, необхідним $є$ надання відповідних соціально-педагогічних послуг. На сьогодні соціальний супровід закріплений на законодавчому рівні як модель цілеспрямованої комплексної допомоги особі або сім'ї та $\epsilon$ обов'язковою умовою функціонування сімей, які виховують прийомних дітей (Капська, 2012, с. 4).

Педагогічна складова є пріоритетною у процесах виховання дітей, позбавлених батьківського піклування, у дитячих будинках сімейного типу, адже саме від цього залежить рівень адаптації дитини у суспільстві, іiі самостійність та дієвість, розвиток творчих здібностей тощо.

Виховання більше п'яти дітей у дитячому будинку сімейного типу вимагає відповідної педагогічної підготовки батьків-вихователів, необхідною умовою $\epsilon$ розроблення методик і соціально-педагогічних умов утримання дітей-сиріт та дітей, позбавлених батьківського піклування. Ті кандидати, що не пройшли курс навчання, не мають права ставати батьками-вихователями. Крім того, діючі батьки-вихователі для підвищення свого виховного потенціалу повинні проходити навчання один раз на два роки відповідно до програми, затвердженої наказом Міністерства соціальної політики (Положення про дитячий будинок сімейного типу, 2002). Така робота покладена на центри соціальних служб сім’і, дітей та молоді, де здійснюється психолого-педагогічна підготовка батьків-вихователів із метою налагодження стосунків 3 дітьми-сиротами та дітьми, позбавленими батьківського піклування.

На процес виховання дітей у родині впливають такі чинники, як рівень педагогічної культури і психолого-педагогічних знань батьків, ступінь їхньої мотивації й відповідальності за виховання дітей, психологічна атмосфера життя у родині, сімейний побут. Непідготовленість багатьох батьків і матерів до виховання дітей, нерозуміння ними процесу розвитку дитини, невміння розпізнавати характер і ступінь впливу як об'єктивних, так і суб'єктивних чинників соціального середовища на виховання дитини нерідко спричиняють серйозні невдачі у сімейному вихованні, негативно впливають на адаптацію дитини у сім'ї та суспільстві (Доля, 2009, с. 198).

Отже, сучасний дитячий будинок сімейного типу це соціальний інститут становлення особистості дітей-сиріт та дітей, позбавлених батьківського піклування. Особливості дитячого будинку сімейного типу виявляються у створенні соціально-педагогічного середовища, в якому поєднуються ознаки багатодітної сім’ї та соціалізуючого інституту. Основні завдання такого новоутворення спрямовані на встановлення позитивних взаємин між дітьми та батьками-вихователями, налагодження спілкування, формування позитивних умов для розвитку їхніх здібностей. Враховуючи вікові та індивідуальні якості вихованців, їхні риси характеру, вподобання, інтереси, обираються методи виховного впливу та враховуються особливості дитячого будинку сімейного типу.

Важливим завданням є створення середовища перебування вихованців, що базується на дотриманні умов захищеності, моральній підтримці дитини та налагодженні комунікативної системи відносин між членами сім'ї. Ефективність діяльності дитячих будинків сімейного типу полягає у створенні атмосфери довіри, поваги та любові, налагодженні зв'язків між дітьми та формуванні авторитету батьків-вихователів. Соціалізуючим завданням дитячого будинку сімейного типу $\epsilon$ підготовка та набуття соціального досвіду, розширення кола спілкування, засвоєння громадянських обов'язків та прав, формування життєвих поглядів та самооцінки.

Водночас соціально-педагогічна мета дитячого будинку сімейного типу полягає у забезпеченні умов для адаптації дітей-сиріт та дітей, позбавлених батьківського піклування, до соціального середовища, максимальна нейтралізація набутого негативного досвіду, компенсація вад фізичного і психологічного розвитку (Пєша, 2000; Бордіян, 2012).

За цих умов діти-сироти та діти, позбавлені батьківського піклування, поступово стають членами означеного соціального інституту. Однак успішна адаптація дитини до умов дитячого будинку та сімейного оточення може тривати до кількох місяців. Значна роль в адаптаційному періоді покладена на батьків-вихователів та раніше прийнятих дітей. Психологічно комфортне середовище будинку у цей період є визначальним у вихованні дітей, позбавлених батьківського піклування. Батьки-вихователі повинні опанувати педагогічні вміння та навички з метою успішної організації діяльності дитячого будинку сімейного типу. Крім того, вони мають володіти здібностями щодо організації багатодітної родини, вміннями й навичками реально оцінювати ситуацію та вирішувати соціально-педагогічні, освітні, виховні та побутові проблеми.

Особливістю організації дитячого будинку сімейного типу є поєднання особистого та професійного життя батьків-вихователів. Під особистим маємо на увазі організацію родинного мікроклімату, вміння бути господарями родини. Професійну складову розглядаємо як використання необхідних педагогічних знань, умінь та навичок із метою реалізації виховання дітей-сиріт та дітей, позбавлених батьківського піклування. 
У процесі організації діяльності дитячого будинку сімейного типу важливим є застосування ефективних методів корекції під час набуття дітьми-сиротами та дітьми, позбавленими батьківського піклування, соціального досвіду, навичок здійснення морально доцільних учинків і поведінки, розуміння своїх прав і обов'язків.

На сьогодні педагогічною наукою розроблені ефективні технології для роботи 3 дітьми-сиротами та дітьми, позбавлених батьківського піклування, у дитячих будинках сімейного типу. Це насамперед цілеспрямовані методи та методики впливу для реалізації завдань та цілей виховання. Поетапність застосування різноманітних виховних технологій залежить від віку дитини та періоду перебування в дитячому будинку сімейного типу. Визначальним $є$ адаптаційний період, що триває близько десяти місяців. Із метою вирішення завдань адаптації необхідне застосування механізмів педагогічного впливу, зокрема: налагодження комунікативних контактів, залучення до загальних справ сім’і, приклад батьків-вихователів, які мають стати соціальним зразком поведінки.

Однією 3 перших проблем, 3 якою стикаються батьки, є педагогічна занедбаність дітей-сиріт та дітей, позбавлених батьківського піклування. У дітей, які попередньо виховувалися поза сім'єю, зазвичай спостерігаються особливості психічного та фізіологічного розвитку, проблеми у міжособистісних стосунках, недовіра, агресивність, замкнутість. Це безпосередньо впливає на розвиток самоусвідомлення та самооцінки дитини, викликає нестабільність емоційної сфери, відставання у розвитку і засвоєнні моральних норм поведінки. Позитивна налаштованість в означеному питанні з часом сприяє корекції світогляду таких дітей. Із метою вирішення цієї проблеми Я. Бордіяном була запропонована схема виховання, що передбачає два складових компоненти: «Я є приклад» та «Я разом з ними». Згідно 3 означеною схемою батьки наголошують на необхідності переосмислення вихованцями їхнього життєвого досвіду завдяки свідомому сприйняттю (Бордіян, 2012, с. 259).

Для активної діяльності дітей-сиріт та дітей, позбавлених батьківського піклування, застосовують такі організаційні методи: проведення ігор, залучення до трудової діяльності, влаштування різноманітних виховних заходів, спільних прогулянок, виконання конкретних завдань у господарстві. Це сприяє формуванню відчуття відповідальності та розвитку вмінь і навичок роботи в колективі.

У дитячому будинку сімейного типу повинні бути сформовані власні норми поведінки, що базуються на взаємоповазі та сприяють позитивному мікроклімату в родині. Під час виховання дітей-сиріт та дітей, позбавлених батьківського піклування, застосовуються не лише методи заохочення, а й покарання. Із метою коригування світобачення застосовуються методи соціально-психологічної терапії: арттерапія, кольоротерапія, музикотерапія, ігротерапія тощо. Зважаючи на те, що дитячий будинок сімейного типу - це багатодітна родина, важливим $є$ графік та план дій на кожний день та створення перспективного плану життєдіяльності кожного із членів родини на далеку перспективу (екскурсії, поїздки, спільні трудові акції тощо).
Це дає змогу ефективно організовувати життєтворчість, відпочинок, дозвілля та контролювати виконання різноманітних завдань.

Висновки. Отже, дитячий будинок сімейного типу є комплексною формою виховання, утримання дітей-сиріт та дітей, позбавлених батьківського піклування, що поєднує родинне та професійне спрямування. Порівнюючи його з іншими формами опіки, зазначимо, що дитячий будинок сімейного типу базується на природності процесу виховання в середовищі родини та спрямований на налагодження емоційного контакту між дітьми та батьками-вихователями. Застосовування комплексного підходу до виховання та індивідуальних стратегій до кожного вихованця сприяє побудові комфортних взаємостосунків у родині.

Перспективи подалыших досліджень. Зважаючи на розширення мережі дитячих будинків сімейного типу як необхідної умови захисту дітей-сиріт та дітей, позбавлених батьківського піклування, важливим $\epsilon$ розроблення науково-методичного забезпечення їх ефективної діяльності.

\section{СПИСОК ВИКОРИСТАНОЇ ЛІТЕРАТУРИ}

Харчук, Т. Я. (2011). Становлення закладів для дітей-сиріт та дітей, позбавлених батьківського піклування, на різних етапах розвитку суспільства в Україні. URL: http://nbuv.gov.ua/j-pdf/Znpkhist_2011_3_41.pdf (дата звернення: 01.03. 2021).

Нариси 3 історії українського шкільництва (1905-1933): навчальний посібник. (1996) / за ред. О. В. Сухомлинської. Київ: Заповіт. 302 с.

Полтавська трудова колонія ім. М. Горького в документах і матеріалах (1920-1926 роки). (2001) / за ред. І. А. Зязюна. Київ; Полтава. Ч.1. 287 с.

Про створення в республіці дитячих будинків сімейного типу: постанова Ради Міністрів УРСР від 5 жовтня 1988 р. № 318 / ЗП УРСР. № 11. Ст. 45.

Про створення в республіці дитячих будинків сімейного типу: постанова від 5 жовтня 1988 р. № 318. Київ. URL: http://search.ligazakon.ua/1 doc2.nsf/link1/ KP880318.html (дата звернення: 07.03. 2021).

Про затвердження положення про дитячий будинок сімейного типу: постанова Кабінету Міністрів України від 27 квітня 1994 р. № 267. URL: https://zakon. rada.gov.ua/laws/show/267-94-\%D0\%BF\#Text (дата звернення: 07.03. 2021).

Сімейний кодекс України: Закон України від 10.01.2002 р. № 2947-III (ред.01.01.2021 р. ВРУ). URL: https://zakon.rada.gov.ua/laws/show/2947-14\#Text (дата звернення: 07.03. 2021).

Капська, А. Й. Пєша, І. В. (2012). Соціальний супровід різних категорій сімей та дітей: навчальний посібник. Київ: Центр учбової літератури. 232 с.

Про затвердження положення про дитячий будинок сімейного типу: постанова від 26 квітня 2002 р. № 564. URL: https://zakon.rada.gov.ua/laws/show/5642002-\%D0\%BF\#Text (дата звернення: 07.03. 2021).

Доля, I. М. (2009). Дитячі будинки сімейного типу: механізм подолання соціального сирітства в Україні. Стратегічні пріоритети. С. 195-199.

Пєша, I. В. (2000). Соціальне становлення дітей в дитячих будинках сімейного типу: автореф. дис. ... на 
здобуття наук. ступеня канд. пед. наук: спец. 13.00.05 «Соціальна педагогіка». Київ.

Бордіян, Я. (2012). Прийомні сім’ї та дитячі будинки сімейного типу як альтернативна форма влаштування дітей: державно-управлінський проєкт. Ефективність державного управління: збірник наукових праць. №. 30. С. 255-261.

\section{REFERENCES}

Kharchuk, T. Ya. (2011). Stanovlennia zakladiv dlia ditei-syrit ta ditei, pozbavlenykh batkivskoho pikluvannia, na riznykh etapakh rozvytku suspilstva v Ukraini [Establishment of institutions for orphans and children deprived of parental care at different stages of society development in Ukraine]. URL: http://nbuv.gov.ua/j-pdf/ Znpkhist_2011_3_41.pdf (data zvernennia: 01.03.2021). [In Ukrainian].

Narysy $z$ istorii ukrainskoho shkilnytstva (1905-1933): navchalnyi posibnyk [Essays on the history of Ukrainian schooling (1905-1933)]. (1996) / za red. O. V. Sukhomlynskoi. Kyiv: Zapovit. 302 s. [In Ukrainian].

Poltavska trudova koloniia im. M. Horkoho v dokumentakh i materialakh (1920-1926 roky) [M. Gorky Poltava labor colony in documents and materials (19201926)]. (2001) / za red. I. A. Ziaziuna. Kyiv; Poltava. Ch.1. 287 s. [In Ukrainian].

Pro stvorennia v respublitsi dytiachykh budynkiv simeinoho typu [About creation orphanages of family type in the republic]: postanova Rady Ministriv URSR vid 5 zhovtnia 1988 r. № 318 / ZP URSR. № 11. St. 45. [In Ukrainian].

Pro zatverdzhennia polozhennia pro dytiachyi budynok simeinoho typu [On approval of the regulations of family type orphanages]: postanova Kabinetu Ministriv Ukrainy vid 27 kvitnia 1994 r. № 267. URL: https://zakon.rada.gov.ua/laws/show/267-94-\%D0\%BF\#Text (data zvernennia: 07.03.2021). [In Ukrainian].
Simeinyi kodeks Ukrainy: Zakon Ukrainy vid 10.01.2002 r. № 2947-III (red.01.01.2021 r. VRU) [Family Code of Ukraine]. URL: https://zakon.rada.gov.ua/laws/ show/2947-14\#Text (data zvernennia: 07.03. 2021). [In Ukrainian].

Kapska, A. Y. Piesha, I. V. (2012). Sotsialnyi suprovid riznykh katehorii simei ta ditei [Social support for different categories of families and children]: navchalnyi posibnyk. Kyiv: Tsentr uchbovoi literatury. 232 s. [In Ukrainian].

Pro zatverdzhennia polozhennia pro dytiachyi budynok simeinoho typu [On approval of the regulations on family type orphanages]: postanova vid $26 \mathrm{kvitnia}$ 2002 r. № 564. URL: https://zakon.rada.gov.ua/laws/ show/564-2002-\%D0\%BF\#Text (data zvernennia: 07.03. 2021). [In Ukrainian].

Dolia, I. M. (2009). Dytiachi budynky simeinoho typu: mekhanizm podolannia sotsialnoho syritstva $\mathrm{V}$ Ukraini. Stratehichni priorytety [Family type orphanages: a mechanism for overcoming social orphanhood in Ukraine. Strategic priorities]. S. 195-199. [In Ukrainian].

Piesha, I. V. (2000). Sotsialne stanovlennia ditei v dytiachykh budynkakh simeinoho typu [Social formation of children in family type orphanages]: avtoref. dys. ... na zdobuttia nauk. stupenia kand. ped. nauk: spets. 13.00.05 «Sotsialna pedahohika». Kyiv. [In Ukrainian].

Bordiian, Ya. (2012). Pryiomni simi ta dytiachi budynky simeinoho typu yak alternatyvna forma vlashtuvannia ditei: derzhavno-upravlinskyi proiekt [Foster families and family type orphanages as an alternative form of arragement of children: a public administration project]. Efektyvnist derzhavnoho upravlinnia: zbirnyk naukovykh prats. № 30 S. 255-261. [In Ukrainian].

Дата надходження до редакиї: 02.04.2021 p. 